\title{
Party politics and education spending: challenging some common wisdom
}

\author{
Julian L. Garritzmann and Kilian Seng
}

\begin{abstract}
Much literature has analysed parties' influence on public education spending. We challenge this literature on theoretical, methodological and empirical grounds. It is standard to regress expenditure on cabinet seat share weighted party family dummies in time series cross section regressions using 'country year' data. But using 'country year' data artificially inflates the number of cases and leads to biased estimates, as governments usually do not change annually. Second, using party families as proxies for party preferences assumes that parties within families hold similar positions while they differ across families. But this is empirically often not the case. Finally, a historical institutionalist perspective suggests that we should not expect party effects anymore in the first place. Empirically, we propose a new design, using direct measures of party preferences in analyses on govern ment term level. We find that the partisan composition of government did not have any significant effects on education spending from 1995 to 2010 in 21 democ racies.
\end{abstract}

KEY WORDS Education; historical institutionalism; Manifesto Project data; party politics; public spending; time series cross section regressions.

\section{INTRODUCTION}

After several decades of limited scholarly interest, education systems and education policies have recently gained massive prominence in political science (Busemeyer and Trampusch 2011; Gift and Wibbels 2014; Iversen and Stephens 2008; Jakobi et al. 2010). Recent contributions have argued that, how and why the politics of skill formation play a central role in shaping labour markets, welfare states and politico-economic systems in general as well as patterns of inequality and redistribution (Hall and Soskice 2001; Iversen 2005; Iversen and Stephens 2008). Consequently, political scientists have probed politico-economic determinants of education systems, focusing particularly on the impact of governing parties on public education expenditure.

The results of these studies are, however, the subject of ongoing scholarly debate because the empirical patterns are anything but trivial due to the complex (re-)distributive processes at work. While some authors found that left-wing parties increase education expenditure (Boix 1998; Busemeyer 2007; 
Castles 1982, 1989, 1998; Hega and Hokenmaier 2002; Iversen and Stephens 2008; Potrafke 2011a; Schmidt 2002, 2007), others reported that right-wing parties tend to spend more on education (Ansell 2008, 2010; Rauh et al. 2011). Adding to the confusion, still others even found no party effects and assigned this to the increasing influence of deindustrialization (Jensen 2011). Consequently, neither the question if, nor the questions how and why parties influence public education expenditure are satisfactorily answered yet.

Despite these theoretical and empirical disputes, the existing studies conform to one aspect: they all use the same methodological approach. The common procedure is to regress spending on cabinet seat-share weighted party-family dummies in time-series cross-section regressions using country-years as the unit of analysis. In fact, this methodological design is not specific to the skill formation literature, but widely used in the public policy and political economy literature (Plümper et al. 2005).

We challenge this widely accepted methodological standard on three grounds. First, we argue that using country-years as the unit of analysis to analyse government effects artificially inflates the number of cases, as governments usually do not change annually. Thus, common approaches try to explain variance with non-variance, resulting in potentially biased effect sizes and over-confident significance levels. We propose using government terms as the unit of analysis instead and control for government duration, which additionally allows testing whether and how government duration matters.

Second, using party-family dummies as proxies for parties' positions assumes that parties within party families hold similar positions and that parties across families hold different positions. However, we show that this is often not the case. Drawing on the well-established party politics literature, we propose to use direct measures of party preferences instead of indirect proxies and exploit Manifesto Project data (MRG/CMP/MARPOR) (Volkens et al. 2011).

Empirically, we apply both the literature's standard 'country-year' approach and our modified 'government-term' design to all available total and sectoral public education spending data, i.e., for 21 democracies between 1995 and 2010. We analyse education spending on pre-primary, tertiary, and non-tertiary (i.e. primary and secondary) education separately, because different (re-)distributional dynamics are at work (Ansell 2008, 2010; Busemeyer 2014; Garritzmann 2014; Iversen and Stephens 2008). While we find effects of governments on spending when using the common country-year approach, these effects vanish once we switch to our government-term design. This applies equally to total public education spending, as well as to sectoral spending. This indicates that the existing literature's findings (with the exception of Jensen [2011], who also reports a non-finding) are probably statistical artefacts.

Nonetheless, and this is the third contribution of our article, one should not over-hastily interpret these results as proof that 'parties have never mattered'. From a historical institutionalist perspective, we would not expect to find effects of parties on spending for the recent period in the first place, as education systems - just as welfare states in general (Esping-Andersen 1990) - have been 
shaped during a much earlier phase, namely the 1950s to the 1980s (Busemeyer 2014; Garritzmann 2014; Iversen and Stephens 2008). Over time, these systems are likely to have generated positive feedback effects (Pierson 1993), which make radical policy-changes increasingly unlikely and path dependencies very likely, thereby limiting governments' leeway in redesigning the education systems (Busemeyer 2014; Garritzmann 2014, 2015). We present some empirical material that indeed points in this direction. Thus, we also challenge the existing expenditure literature theoretically by adding a historical institutionalist perspective.

In more general terms, while we use education spending to exemplify our claims, our methodological and theoretical arguments should equally hold for many other public (welfare) expenditure fields. The article therefore contributes substantially to the skill formation and welfare state literature, as well as to the public policy and political economy literature in general.

We proceed as follows: next, we summarize the existing literature, focusing particularly on their methodologies. We identify existing methodological pitfalls and propose an alternative approach. Afterwards, we turn from methods to substance and discuss for which parties we should expect effects. We then criticize the standard operationalization of party preferences and propose a more direct measure. The following section presents the research design and empirical results. Thereafter, we apply a historical institutionalist perspective to the findings. The final part concludes, discusses some broader implications, and points at opportunities for future research.

\section{PARTY INFLUENCE ON EDUCATION SPENDING: METHODOLOGICAL PROGRESS AND REMAINING PITFALLS}

As education policies recently witnessed a huge upswing in scholarly interest (Busemeyer and Trampusch 2011; Gift and Wibbels 2014; Iversen and Stephens 2008; Jakobi et al. 2010), political scientists began to ask: do governing parties influence education systems? Scholars particularly investigated whether and how governments have affected public education spending as a policy output that can easily be compared across countries and time (full citations below). In the following, we first focus on the existing literature's methodology because we argue that the literature's findings might be fundamentally biased due to a methodological misspecification.

In order to investigate governments' effects on expenditure, decent methodological progress has been achieved. The first studies (Castles 1982; Verner 1979) used very simple statistical tools and just analysed correlations between government compositions and expenditures. Subsequent more elaborated analyses (Boix 1998; Castles 1989, 1998; Hega and Hokenmaier 2002) tested the explanatory power of various determinants in (repeated) cross-sectional multivariate regressions. Still newer contributions (Ansell 2008, 2010; Busemeyer 2006, 2007, 2009; Iversen and Stephens 2008; Jensen 2011; Potrafke 2011a, 2011b; Rauh et al. 2011) applied pooled time-series cross-section (TSCS) 
regressions to annual data to analyse governing parties' impact on education spending. Hitherto, pooled TSCS regressions on annual data have become the methodological standard to estimate government effects on expenditure. In fact, this methodological design is not specific to the skill formation literature, but widely used in the public policy and political economy literature (Plümper et al. 2005).

We argue that while decent progress has been made, this methodological standard might mis-estimate the effects of governments on expenditure. This is so because of the focus on annual data ('country-years'). While (education) expenditure can indeed vary from year to year, the partisan composition of government usually does not change annually but rather at elections (or sometimes within an election cycle). The partisan composition of government can thus only be measured once per government term. Using country-years as the unit of analysis therefore artificially inflates the number of observations. Consequently, common approaches try to explain variance (education spending) with non-variance (government composition), resulting in potentially biased effect sizes and overconfident significance levels. In short: the existing literature's findings might be wrong.

Thus, we propose to abstain from utilizing this 'artificial' annual observation data when investigating effects of governments. Instead, we propose a straightforward alternative: government terms as the unit of analysis. Although using government terms seems to be a much more convincing and straightforward approach, it has not been applied in the literature yet (exceptions in other policy areas are Persson et al. [2007]; Schmitt [2013]; Vis [2011, 2012]; but Persson et al. analyze total government spending, whereas Schmitt focuses on total public welfare expenditure; $\mathrm{V}$ is concentrates on active labour market policies [ALMPs]). Accordingly, the first contribution of our article is the introduction of a more convincing research design that captures parties' effects more accurately.

Moreover, our government-term approach has additional advantages over country-year approaches. Using country-years either assumes an immediate effect of governments on expenditure or necessitates the specification of a lag structure stating when exactly the effect is expected to materialize. Usually, this is assumed to be one year. However, this is arbitrarily chosen and governments might need more time to affect expenditure. Moreover, the lag structure of the effects might vary across countries (and time). Complicating things further, governments can also schedule the time-point for reforms, e.g., towards the beginning or the end of their term. Consequently, approaches relying on country-year basis have to deal with many nontrivial time issues.

Our government-term approach, in contrast, has the advantage that many of the time issues are less problematic, because it only assumes that governments have effects at some point during their term. Moreover, we can control for government duration, defined as the number of days in office, which additionally allows testing whether and how government duration matters. Finally, government-term observations are also less sensitive to exogenous shocks than annual observations, facilitating analysis even further. 
In sum, by moving from country-years to government terms as the unit of analysis, we can estimate the effects of governments more accurately and facilitate the analysis.

\section{PARTY INFLUENCE ON EDUCATION SPENDING: FROM LEFT - RIGHT DICHOTOMIES TO PARTY-FAMILY APPROACHES}

Turning from methods to substance, which parties should we expect to increase or decrease public education expenditure? In order to answer this question, scholars deduced expectations from the famous partisan hypothesis (Hibbs 1977; Castles 1982; Schmidt 1996). Following partisan hypothesis's simple, original form, early studies deduced expectations from the left-right continuum (Boix 1998; Castles 1982, 1989, 1998; Hega and Hokenmaier 2002; Verner 1979). They argued that left-wing parties spend more on education (vis-à-vis right-wing parties) because education could foster equality of opportunities, socioeconomic upward mobility, and redistribution. Boix (1998) proposed a supplementary argument, reasoning that in a globalized world Keynesian 'demand-side politics' would not be feasible anymore, or at least less powerful as before. Deprived of this policy tool, left-wing parties would rather focus on 'supply-side policies', especially on investment in human capital.

Subsequent more elaborated approaches contended that the left-right 'superissue' allows deriving first hypotheses, but does not cover party positions on education adequately. Schmidt (1996: 158), for example, argued that:

the distinction between leftist and rightist parties disregards a large proportion of the variation in political-ideological orientations ... including the differences between social democratic parties and communist parties, and the dividing line between social democracy and leftist ecological parties.

That is, neither all left-wing nor all right-wing parties hold the same education policy position. Focusing especially on Christian democrats, scholars demonstrated that the patterns of party preferences are more complex than simple left-right divides suggest: despite being right-wing in many terms, Christian democrats were found to be important proponents of education policies (Busemeyer 2007, 2014; Iversen and Stephens 2008). ${ }^{2}$ Similarly, liberal parties do not fit neatly into the simple left-right picture, as they can be of a leftleaning or a right-leaning type and hold very different positions depending on to which branch of liberal parties they belong. Moreover, social democrats seem to be more obliged to education than other left-wing parties (Ansell 2010; Busemeyer 2006, 2009; Busemeyer et al. 2013).

Consequently, these scholars proposed using party families as a more finegrained differentiation than left-right dichotomies (Ansell 2010; Busemeyer 2006, 2007, 2009; Jensen 2011; Potrafke 2011b; Schmidt 2002, 2007; Wolf and Zohlnhöfer 2009). Empirical studies underlined this, claiming that parties within the broader left-right camps indeed behave differently. For example, liberals and Christian democrats were argued to increase education 
spending (at least in times of economic prosperity [Busemeyer 2006]), whereas conservative parties are potentially negatively associated with education spending (Busemeyer 2006; Schmidt 2007). Moreover, differentiating between spending on different education sectors, social democrats were argued to increasingly focus on tertiary education, while conservative and Christian democratic government participation is negatively associated with public tertiary education spending (Boix 1998; Busemeyer 2006, 2009).

Jensen (2011), however, raised a critical voice against all previous studies, arguing that education is 'among the least redistributive government programs' (413), and inferred that we should not expect party effects on education spending in the first place. Instead, he contended that deindustrialization is the main driver of education expenditure, because deindustrialization increases (highskilled) workers' risk exposure, which again is believed to transfer into higher spending (particularly in co-ordinated market economies [CMEs]). Jensen's empirical analyses confirm this reasoning, as he does not find any effects of the partisan composition of government, but instead effects of deindustrialization (in CMEs). Consequently, according to this view it should not matter whether we use left-right dummies or party families - parties should not matter in the first place.

In sum, by switching from simple left-right dichotomies to party families, newer contributions to the literature attempted to provide deeper insights into party influences on education spending. Subsequently, using party families became the standard in the literature.

\section{IS THE USUAL PARTY FAMILY APPROACH THE BEST WE CAN DO?}

Our second contribution is that we challenge the use of party-families. Without doubt, party families offer a straightforward classification, which is probably the smallest theoretically meaningful unit to bracket parties. Nevertheless, using party families bears several assumptions, of which two should receive attention here: one has to assume that parties within families hold the same positions towards education policies (spending in particular) and that parties of different families hold different positions.

Yet, both assumptions are empirically often not true. In fact, we can bring forward the same arguments against the party family approach that advocates of this approach made vis-à-vis the left-right dichotomy: it is neither the case that all parties within each family hold the same position towards education, nor that parties of different families necessarily hold different preferences.

While empirical investigations of parties' education policy preferences are surprisingly scarce, Busemeyer et al. (2013) have recently demonstrated in an analysis of 1,800 manifestos in 18 democracies between 1945 and 2010 that party preferences towards education indeed vary considerably across 'the Left' and 'the Right' as well as across party families (cf. also Ansell [2010]; Jungblut [2014]). Furthermore, considerable variation exists both across countries and 
time. Consider three examples: in Denmark, education expansion is emphasized the most by left-wing parties, while it is a right-wing issue in Norway (Busemeyer et al. 2013: Table 3). In the United Kingdom, expansion was initially emphasized by the Conservatives, but has been 'owned' by Labour since the 1980s (ibid.). Finally, while the liberal Høyre in Norway is a strong proponent of education expansion, its Swedish sister party (Moderaterna) is an issueignorer' (ibid.: Table 2).

As these examples illustrate, parties' preferences on education vary not only across countries and time, but also across party families. Accordingly, assuming all parties within a family to hold similar positions and across families to hold different positions are two assumptions that often are empirically not true. Consequently, we might systematically mis-estimate effects of parties on spending when using simple left-right dichotomies or party family approaches. In Online Appendix A, we underpin this finding more systematically with empirical data.

We conclude that approaches simply assuming party preferences to differ across the left-right dichotomy or across party families might be misleading, resulting in biased estimations of parties' effects on policy outputs. Besides, three supplementary arguments can be brought forward against proxying for party positions with party family dummies. First, focusing on party families shifts away the focus of the question that scholars were originally attempting to answer, i.e., 'Do parties matter for (education) spending?' to 'Do different party families behave differently with regard to (education) spending?' Second, all of the cited studies only consider a few party families, assuming that only the mainstream parties matter (see also the criticism in Jensen [2010, 2011]). Other party families (e.g., Communists, Greens or Liberals) are usually ignored, despite the fact that they have often been pivotal in determining policy outputs. Third, questioning party family approaches receives much support from the party politics literature where utilizing party families as proxies for parties' positions is regarded as a heuristically helpful, but outdated and too broad-brushed an approach (Mair 2001).

Taking all these arguments together, we might mis-estimate parties' influence on policy outputs when using left-right dichotomies or party-family approaches.

\section{FROM INDIRECT TO DIRECT MEASURES OF PARTY PREFERENCES}

Instead of using these indirect approaches, we propose exploiting direct measures of parties' education preferences. The Manifesto Project (CMP/ MRG/MARPOR) makes such a direct measure available by coding manifestos into issue categories (Volkens et al. 2011). One of the categories is 'Education Expansion' (per506), defined as: 'Need to expand and/or improve educational provision at all levels'. ${ }^{3}$ This is a very fitting measure of parties' education preferences, as we can expect that 'education expansion and/or improvement' are 
directly linked to education spending and that parties (and voters) will be aware of this. As the CMP covers 3,334 manifestos for 840 parties between 1945 and 2010, comparative analyses across countries and time are feasible.

Nevertheless, several disadvantages of the data should also be mentioned. A first problem is that the education item is defined in very broad terms ('education expansion and/or improvement') and consequently does not differentiate between educational sectors. We know, however, that different political dynamics are at play in different sectors due to different (re-) distributive characteristics (Ansell 2008, 2010; Busemeyer 2009, 2014; Garritzmann 2014; Iversen and Stephens 2008). For example, tertiary education can be financially progressive or regressive, depending on the enrolment rate (Ansell 2008, 2010) and the way of financing the system (Garritzmann 2014). Ideally, we would have a more fine-grained coding scheme, but these data are unfortunately unavailable.

Second, the data are available only for the national level, but the major decision-making competence for education policies lies on the subnational level in some (federal) countries. Although some efforts have been made to code subnational manifestos in some countries (e.g., Bräuninger and Debus 2008), to our knowledge no comparative dataset on subnational parties exists. However, the focus on national parties seems justified, as we want to relate our findings to the existing literature (as we make strong claims vis-à-vis the state of the art), where it is common practice to focus on the national level (but see Rauh et al. 2011). Moreover, comparative public spending data is only available for this level. Finally, in the analyses we will control for the governance structure. ${ }^{4}$

Consequently, we are confident that the selected item (per506) is a valid measure of parties' preferences towards education spending. Hitherto, the CMP data has only been used in a single study in order to explain education spending (Ansell 2010: 141-3). Ansell includes the 'per506' item in his regressions in addition to parties' cabinet seat-shares to test whether rhetoric is only 'cheap talk' (ibid.: 136) or whether it has a substantive effect. He finds no independent effect of manifesto statements on public education spending in absolute terms. Predicting relative education spending (vis-à-vis other policy fields), however, the variable shows a significant effect. While Ansell deserves much praise for his efforts of probing party effects on education, his analysis can be improved because he does not distinguish between different education sectors, incorporates only few control variables and model specifications, and applies the country-year approach that we criticize. Our second contribution to the literature is thus to incorporate a direct measure of parties' education policy preference instead of utilizing indirect measures into a systematic analysis. The expectation is very simple: The more emphasis government parties place on education, the higher public education spending should be.

\section{RESEARCH DESIGN}

In order to test our arguments, we present and compare results of three different set-ups. First, we replicate the literature's standard approach and conduct 
analyses using country-years as the unit of analysis. Second, we change the unit of analysis to government terms and analyse whether this alters the results. Finally, we test whether using a direct measure instead of the indirect party family approach affects the findings.

All three set-ups are applied to the same data so that the results can be easily compared. We use all publicly available data that allow differentiating spending on the different education sectors, which leaves us with data for 21 democracies between 1995 and 2010. ${ }^{5}$ Unfortunately, as has been discussed by many others (Ansell 2008, 2010; Busemeyer 2009, 2014; Heidenheimer 1996; Jensen 2011; Schmidt 2007), data allowing for differentiation between education sectors are unavailable for more countries or a longer time frame. As pointed out above, the distinction between different sectors is crucial, however, because very different (re-)distributive dynamics are at work. For example, spending on primary and secondary education is likely to be financially progressive, while spending on higher education can be financially regressive in some circumstances (Ansell 2008, 2010; Garritzmann 2014; Iversen and Stephens 2008). Thus, effects of parties are likely to vary across sectors. As is customary in the literature, we distinguish between spending on primary, secondary and tertiary education. Moreover, we add spending on pre-primary education, which has recently featured very prominently in the literature on the 'social investment state' (for many: Bonoli [2007]; Esping-Andersen [2002]) but has empirically been neglected in existing studies. Thus, we test the influence of parties on total, as well as on sectoral public education spending.

The dependent variables are total as well as sectoral public education spending as a share of the gross domestic product (GDP). ${ }^{6}$ In the first set-up, this is used on an annual basis; afterwards, we average the dependent variable over each government term.

Concerning the independent variable (governments' policy-preferences), we use two operationalizations. First, we apply the literature's standard approach and weight party family dummies by the respective parties' cabinet seat-shares. Next, we use the CMP's 'education expansion' item (per506) as an alternative operationalization of party preferences. As the CMP 'only' offers data for single parties and not for (coalition) governments, we calculate government positions by taking the average of the preferences of the respective government parties, weighted by the respective cabinet seat-share, i.e., a 'centre of gravity' for governing parties (Cusack and Engelhardt 2002). Put mathematically:

Government' $s_{i t}$ education expansion preference

$$
\begin{aligned}
= & \frac{1}{N} \sum_{i=1}^{n} \text { (cabinet seat share party } 1 \cdot \text { party } 1^{\prime} \text { s per } 506 \text { value at time } t \\
& \left.+\cdots+\text { cabinet seat share party } n^{\bullet} \text { party } n^{\prime} \text { s per } 506 \text { value at time } t\right)
\end{aligned}
$$


As various rival explanations for public (education) spending have been identified in the literature, common control variables are also included, but not of theoretical interest here. These are (see Busemeyer [2009: 113] for a comprehensive discussion): trade openness (the average exports and imports as a percentage of GDP); 'demand' for education (covered by the population aged 65+ divided by those between 5 and 29); female labour force participation (for females aged 15-64); the level and change of economic well-being (gross national income [GNI] per capita); the total level of public spending as a percentage of GDP; and the level of gross public domestic debt as a share of GDP. Descriptive statistics on all variables are provided in Online Appendix B. As additional robustness tests, we also controlled for decision-making capacities (federalism). The results remained unaltered.

Concerning model specifications, a panel difference-in-difference estimator with additional control variables is theoretically most compelling to us: it measures how changes from one government to another affect (subsequent) changes in spending. The dependent variable is the difference between the average expenditure share in the actual government period and the previous period. The independent variable is the difference between the current and the previous government's preference. We control for the original level of education spending and also include lagged independent variables to better compare the results to other studies: Iversen and Cusack (2000) and Busemeyer (2009) interpret the lagged independent variables as 'long-term effects' and the first-differences as 'short-term effects'. Thus, we estimate the following equation:

$$
\Delta y_{i t}=\alpha+\beta_{1} \Delta \boldsymbol{X}_{i t}+\beta_{2} \boldsymbol{X}_{i t}{ }_{1}+\beta_{3} y_{i t}{ }_{1}+\varepsilon_{i t}
$$

where $\mathrm{y}$ is the dependent variable, $\alpha$ is a constant term, $\mathbf{X}$ is a vector of independent variables, $\varepsilon$ is the idiosyncratic error, and $\Delta$ is the first-difference operator.

As robustness checks, we also test several other model specifications. The simplest one is a pooled estimator with country-clustered standard errors. ${ }^{7}$ As some of the dependent variables inherit first-order serial-correlation, we account for that by a correction of the standard errors. Moreover, we run the models as fixed and random effects panel estimators (a Hausman test suggests that the fixed effect estimator is more appropriate due to the amount of unobserved heterogeneity).

As discussed above, we first present models using the standard setting, i.e., country-years as the unit of analysis. After deletion of missing values, 245 observations are used in these estimations. We then switch to our proposed design, using government terms. Overall, this leaves us with 114 observations. The analyses on country-year thus artificially adds 131 ( $245-114)$ 'observations' without variance on the independent variable, leading to potentially biased coefficients and too small standard errors. ${ }^{8}$ 


\section{EMPIRICAL RESULTS}

\section{Results on country-year basis}

Table 1 presents findings utilizing country-year data. We show four different model specifications regressing total public education spending on the cabinet seat-shares of social democratic parties. We focus on social democrats because earlier studies argued and found that they are more obliged to education (Ansell 2008, 2010; Busemeyer 2006, 2009; Iversen and Stephens 2008; Schmidt 2007) and emphasize education more in their manifestos (Ansell 2010; Busemeyer et al. 2013). Nonetheless the results are robust when we include other party families' seat-shares or broader left-right categories.

The main take-away is that - in line with Ansell $(2008,2010)$, Busemeyer (2006, 2009), Iversen and Stephens (2008), and others - we find that social democratic governments are associated with larger education spending - at least in the long run. We do not find a short-term effect (first differences), but the lagged-level seat-share variable is significant. Moreover, reproducing the results of Boix (1998) and Busemeyer (2009), we find a significant effect of trade openness: more open economies are characterized by higher spending (lagged-level). Thus, when using country-years as the unit of analysis we are able to replicate the literature's findings (but see Jensen [2011] for a different finding) that left-wing parties increase education spending.

\section{Results on government-term basis}

We claimed that effects of governments on spending might be mis-estimated in country-year designs and switch the unit of analysis now to government terms. Regressing the four different measures of the dependent variable (public spending on pre-primary, tertiary, non-tertiary, as well as total public education spending) on the cabinet seat-shares of social democrats and the control variables leads neither to substantial nor to significant effects. Different model specifications do not show any robust results. To exemplify this, Table 2 shows results for total public education spending and spending on tertiary education: ${ }^{9}$ Models 5 and 6 use the seat-shares of social democratic parties as independent variable (lagged and first differences). Yet, we do not find any significant effect, as the estimated coefficients are very small and not significant. The model fit for tertiary education spending is even lower than for total education spending. ${ }^{10}$

Moreover, we test whether the results are driven by the focus on social democrats' government participation. This is not the case; using other party families or broader left-right categories leaves the results unchanged (results on request). That is, in contrast to the existing literature (except Jensen [2011], who reports a non-finding) and our replication thereof, we do not find any effects of the partisan composition of government on education spending when using government terms as the unit of analysis. This supports our claim that the literature's findings might be driven by the artificial inflation of the number of cases due to the focus on annual observations. 
Table 1 Regression of total public education spending; country-year basis

\begin{tabular}{|c|c|c|c|c|}
\hline Variable & $\begin{array}{c}(1) \\
\text { Baseline }\end{array}$ & $\begin{array}{l}(2) \\
\text { LDV }\end{array}$ & $\begin{array}{c}(3) \\
\operatorname{AR}(1)\end{array}$ & $\begin{array}{c}(4) \\
\operatorname{PSAR}(1)\end{array}$ \\
\hline $\begin{array}{l}\text { Social democ. } \\
\text { cabinet seat- } \\
\text { share }(t-1)\end{array}$ & $\begin{array}{c}0.000927^{* *} \\
(0.000392)\end{array}$ & $\begin{array}{c}0.000804^{* *} \\
(0.000386)\end{array}$ & $\begin{array}{c}0.000904^{* *} \\
(0.000360)\end{array}$ & $\begin{array}{c}0.000955^{* *} \\
(0.000442)\end{array}$ \\
\hline $\begin{array}{l}\text { Social democ. } \\
\text { cabinet seat- } \\
\text { share }(\Delta)\end{array}$ & $\begin{array}{c}0.000267 \\
(0.000771)\end{array}$ & $\begin{array}{c}0.000146 \\
(0.000758)\end{array}$ & $\begin{array}{c}0.000168 \\
(0.000734)\end{array}$ & $\begin{array}{c}0.000252 \\
(0.000658)\end{array}$ \\
\hline $\begin{array}{l}\text { Trade openness } \\
\qquad(\mathrm{t}-1)\end{array}$ & $\begin{array}{c}0.00109^{* * *} \\
(0.000310)\end{array}$ & $\begin{array}{l}0.00115^{* * *} \\
(0.000313)\end{array}$ & $\begin{array}{l}0.00106 * * * \\
(0.000285)\end{array}$ & $\begin{array}{c}0.00108^{* * *} \\
(0.000243)\end{array}$ \\
\hline Trade openness $(\Delta)$ & $\begin{array}{c}-0.00751^{* *} \\
(0.00314)\end{array}$ & $\begin{array}{c}-0.00747^{* *} \\
(0.00306)\end{array}$ & $\begin{array}{c}-0.00789^{* *} \\
(0.00309)\end{array}$ & $\begin{array}{c}-0.00719^{* *} \\
(0.00293)\end{array}$ \\
\hline $\begin{array}{l}\text { Gross publ. debt } \\
(t-1)\end{array}$ & $\begin{array}{l}-8.71 e-05 \\
(0.000727)\end{array}$ & $\begin{array}{r}-0.000139 \\
(0.000687)\end{array}$ & $\begin{array}{r}-7.94 e-05 \\
(0.000679)\end{array}$ & $\begin{array}{l}6.61 e-05 \\
(0.00113)\end{array}$ \\
\hline Gross publ. debt $(\Delta)$ & $\begin{array}{c}0.00554 \\
(0.00433)\end{array}$ & $\begin{array}{l}0.00295 \\
(0.00410)\end{array}$ & $\begin{array}{c}0.00463 \\
(0.00419)\end{array}$ & $\begin{array}{c}0.00383 \\
(0.00363)\end{array}$ \\
\hline Age ratio $(t-1)$ & $\begin{array}{c}0.0157 \\
(0.150)\end{array}$ & $\begin{array}{l}-0.0712 \\
(0.138)\end{array}$ & $\begin{array}{l}0.000896 \\
(0.140)\end{array}$ & $\begin{array}{l}-0.0412 \\
(0.130)\end{array}$ \\
\hline Age ratio $(\Delta)$ & $\begin{array}{c}0.316 \\
(2.163)\end{array}$ & $\begin{array}{l}-0.934 \\
(2.068)\end{array}$ & $\begin{array}{c}0.552 \\
(1.984)\end{array}$ & $\begin{array}{c}1.400 \\
(1.630)\end{array}$ \\
\hline $\begin{array}{l}\text { National income per } \\
\text { capita }(t-1)\end{array}$ & $\begin{array}{c}2.21 \mathrm{e}-06 \\
(3.22 \mathrm{e}-06)\end{array}$ & $\begin{array}{c}1.77 e-06 \\
(3.05 e-06)\end{array}$ & $\begin{array}{c}2.39 \mathrm{e}-06 \\
(2.96 \mathrm{e}-06)\end{array}$ & $\begin{array}{c}3.73 e-06 \\
(2.62 \mathrm{e}-06)\end{array}$ \\
\hline $\begin{array}{l}\text { National income per } \\
\text { capita }(\Delta)\end{array}$ & $\begin{array}{l}-5.12 \mathrm{e}-05^{* * *} \\
(1.36 \mathrm{e}-05)\end{array}$ & $\begin{array}{l}-4.96 \mathrm{e}-05^{* * *} \\
(1.32 \mathrm{e}-05)\end{array}$ & $\begin{array}{l}-4.95 e-05^{* * *} \\
(1.33 e-05)\end{array}$ & $\begin{array}{l}-5.34 \mathrm{e}-05^{* * *} \\
(1.24 \mathrm{e}-05)\end{array}$ \\
\hline $\begin{array}{l}\text { Public disbursement } \\
(t-1)\end{array}$ & $\begin{array}{c}-0.00259 \\
(0.00166)\end{array}$ & $\begin{array}{c}0.00419 \\
(0.00369)\end{array}$ & $\begin{array}{l}-0.00227 \\
(0.00154)\end{array}$ & $\begin{array}{c}-0.00274 \\
(0.00198)\end{array}$ \\
\hline $\begin{array}{l}\text { Public disbursement } \\
(\Delta)\end{array}$ & $\begin{array}{c}0.0286^{* * *} \\
(0.00917)\end{array}$ & $\begin{array}{l}0.0311^{* * *} \\
(0.00911)\end{array}$ & $\begin{array}{c}0.0307^{* * *} \\
(0.00926)\end{array}$ & $\begin{array}{c}0.0304^{* * *} \\
(0.00859)\end{array}$ \\
\hline $\begin{array}{l}\text { Female labour force } \\
\text { particip. rate }(t-1)\end{array}$ & $\begin{array}{l}-0.00132 \\
(0.00224)\end{array}$ & $\begin{array}{c}0.00301 \\
(0.00285)\end{array}$ & $\begin{array}{l}-0.00135 \\
(0.00204)\end{array}$ & $\begin{array}{c}-0.000381 \\
(0.00210)\end{array}$ \\
\hline $\begin{array}{c}\text { Female labour force } \\
\text { particip. rate }(\Delta)\end{array}$ & $\begin{array}{l}-0.0203 \\
(0.0190)\end{array}$ & $\begin{array}{c}-0.0251 \\
(0.0183)\end{array}$ & $\begin{array}{l}-0.0189 \\
(0.0180)\end{array}$ & $\begin{array}{l}-0.0118 \\
(0.0168)\end{array}$ \\
\hline $\begin{array}{l}\text { Total public } \\
\text { education } \\
\text { spending }(t-1)\end{array}$ & & $\begin{array}{c}-0.0690^{* *} \\
(0.0322)\end{array}$ & & \\
\hline Constant & $\begin{array}{c}0.111 \\
(0.146) \\
\end{array}$ & $\begin{array}{l}-0.00940 \\
(0.167) \\
\end{array}$ & $\begin{array}{c}0.0983 \\
(0.135) \\
\end{array}$ & $\begin{array}{c}0.0208 \\
(0.162) \\
\end{array}$ \\
\hline Observations & 245 & 245 & 245 & 245 \\
\hline $\mathrm{R}$-squared & 0.417 & 0.439 & 0.437 & 0.480 \\
\hline Wald Test & $291.23^{* * *}$ & $214.11^{* * *}$ & $206.58^{* * *}$ & $259.29 * * *$ \\
\hline Number of countries & 21 & 21 & 21 & 21 \\
\hline
\end{tabular}

Notes: Standard errors in parentheses. Significance levels: ${ }^{* * *} p<0.01$; ${ }^{* *} p<0.05$; $* \mathrm{p}<0.1$.

$\mathrm{LDV}=$ Lagged dependent variable; $\mathrm{AR}=$ Autoregressive model; PSAR(1) $=$ Panelspecific $A R(1)$ process. 
Table 2 Regression of total and tertiary education spending; government-term basis

\begin{tabular}{|c|c|c|c|c|}
\hline Variable & $\begin{array}{c}(5) \\
\Delta \text { Total } \\
\text { public } \\
\text { education } \\
\text { spending }\end{array}$ & $\begin{array}{c}\text { (6) } \\
\Delta \text { Public } \\
\text { tertiary } \\
\text { education } \\
\text { spending }\end{array}$ & $\begin{array}{c}(7) \\
\Delta \text { Total } \\
\text { public } \\
\text { education } \\
\text { spending }\end{array}$ & $\begin{array}{c}(8) \\
\Delta \text { Public } \\
\text { tertiary } \\
\text { education } \\
\text { spending }\end{array}$ \\
\hline $\begin{array}{l}\text { Total public } \\
\text { education } \\
\text { spending }(t-1)\end{array}$ & $\begin{array}{c}-0.0945 \\
(0.0827)\end{array}$ & & $\begin{array}{l}-0.103 \\
(0.0763)\end{array}$ & \\
\hline $\begin{array}{l}\text { Public tertiary } \\
\text { education } \\
\text { spending }(t-1)\end{array}$ & & $\begin{array}{c}-0.0759 \\
(0.160)\end{array}$ & & $\begin{array}{c}-0.0752 \\
(0.158)\end{array}$ \\
\hline $\begin{array}{l}\text { Social democ. } \\
\text { cabinet seat- } \\
\text { share }(t-1)\end{array}$ & $\begin{array}{c}0.00145 \\
(0.00100)\end{array}$ & $\begin{array}{c}0.000218 \\
(0.000615)\end{array}$ & & \\
\hline $\begin{array}{l}\text { Social democ. } \\
\text { cabinet seat- } \\
\text { share }(\Delta)\end{array}$ & $\begin{array}{c}0.000296 \\
(0.00109)\end{array}$ & $\begin{array}{c}5.89 e-05 \\
(0.000618)\end{array}$ & & \\
\hline $\begin{array}{l}\text { Gov.'s educ. } \\
\text { expansion } \\
\text { preference }(t-1)\end{array}$ & & & $\begin{array}{c}0.0191 \\
(0.0184)\end{array}$ & $\begin{array}{c}0.0121^{*} \\
(0.00709)\end{array}$ \\
\hline $\begin{array}{l}\text { Gov.'s educ. } \\
\text { expansion } \\
\text { preference }(\Delta)\end{array}$ & & & $\begin{array}{c}0.00187 \\
(0.00646)\end{array}$ & $\begin{array}{c}0.00362 \\
(0.00503)\end{array}$ \\
\hline $\begin{array}{l}\text { Trade openness } \\
\qquad(t-1)\end{array}$ & $\begin{array}{c}0.00257^{* * *} \\
(0.000933)\end{array}$ & $\begin{array}{r}-0.000459 \\
(0.000638)\end{array}$ & $\begin{array}{c}0.00278^{* * *} \\
(0.000860)\end{array}$ & $\begin{array}{l}-0.000205 \\
(0.000543)\end{array}$ \\
\hline Trade openness $(\Delta)$ & $\begin{array}{r}-0.00190 \\
(0.00333)\end{array}$ & $\begin{array}{c}0.000472 \\
(0.00125)\end{array}$ & $\begin{array}{l}-0.00122 \\
(0.00394)\end{array}$ & $\begin{array}{c}0.000750 \\
(0.00119)\end{array}$ \\
\hline $\begin{array}{l}\text { Gross public debt } \\
(t-1)\end{array}$ & $\begin{array}{c}-0.000338 \\
(0.00217)\end{array}$ & $\begin{array}{c}0.000431 \\
(0.00108)\end{array}$ & $\begin{array}{c}-0.000289 \\
(0.00187)\end{array}$ & $\begin{array}{c}0.000486 \\
(0.000999)\end{array}$ \\
\hline Gross public debt $(\Delta)$ & $\begin{array}{c}-0.000231 \\
(0.00378)\end{array}$ & $\begin{array}{l}-0.00273 \\
(0.00379)\end{array}$ & $\begin{array}{c}-0.000279 \\
(0.00344)\end{array}$ & $\begin{array}{c}-0.00263 \\
(0.00374)\end{array}$ \\
\hline Age ratio $(t-1)$ & $\begin{array}{c}-0.397 \\
(0.368)\end{array}$ & $\begin{array}{r}-0.219 \\
(0.291)\end{array}$ & $\begin{array}{l}-0.159 \\
(0.281)\end{array}$ & $\begin{array}{l}-0.145 \\
(0.307)\end{array}$ \\
\hline Age ratio $(\Delta)$ & $\begin{array}{c}1.188 \\
(1.673)\end{array}$ & $\begin{array}{c}1.344 \\
(1.012)\end{array}$ & $\begin{array}{c}1.223 \\
(1.666)\end{array}$ & $\begin{array}{c}1.575 \\
(1.049)\end{array}$ \\
\hline $\begin{array}{l}\text { National income per } \\
\text { capita }(t-1)\end{array}$ & $\begin{array}{c}-2.86 e-06 \\
(5.85 e-06)\end{array}$ & $\begin{array}{c}-2.43 e-06 \\
(5.14 \mathrm{e}-06)\end{array}$ & $\begin{array}{l}-6.74 e-06 \\
(5.07 e-06)\end{array}$ & $\begin{array}{c}-2.89 e-06 \\
(5.02 e-06)\end{array}$ \\
\hline $\begin{array}{l}\text { National income per } \\
\text { capita }(\Delta)\end{array}$ & $\begin{array}{c}-1.10 \mathrm{e}-05 \\
(1.52 \mathrm{e}-05)\end{array}$ & $\begin{array}{c}-1.51 \mathrm{e}-05 \\
(1.10 \mathrm{e}-05)\end{array}$ & $\begin{array}{l}-1.41 \mathrm{e}-05 \\
(1.64 \mathrm{e}-05)\end{array}$ & $\begin{array}{c}-1.73 e-05 \\
(1.12 e-05)\end{array}$ \\
\hline $\begin{array}{l}\text { Public disbursement } \\
(\mathrm{t}-1)\end{array}$ & $\begin{array}{l}0.00670 \\
(0.0117)\end{array}$ & $\begin{array}{c}0.00268 \\
(0.00681)\end{array}$ & $\begin{array}{l}0.00586 \\
(0.0114)\end{array}$ & $\begin{array}{c}0.00152 \\
(0.00709)\end{array}$ \\
\hline $\begin{array}{l}\text { Public disbursement } \\
(\Delta)\end{array}$ & $\begin{array}{l}0.0658^{* * *} \\
(0.0100)\end{array}$ & $\begin{array}{r}0.0174^{* *} \\
(0.00794)\end{array}$ & $\begin{array}{c}0.0675^{* * *} \\
(0.00964)\end{array}$ & $\begin{array}{r}0.0162^{* *} \\
(0.00753)\end{array}$ \\
\hline $\begin{array}{l}\text { Female labor force } \\
\text { particip. rate }(t-1)\end{array}$ & $\begin{array}{c}0.00265 \\
(0.00616)\end{array}$ & $\begin{array}{c}0.00555 \\
(0.00568)\end{array}$ & $\begin{array}{c}0.00568 \\
(0.00518)\end{array}$ & $\begin{array}{c}0.00621 \\
(0.00589)\end{array}$ \\
\hline
\end{tabular}


Table 2 Continued

\begin{tabular}{lcccc}
\hline & $(5)$ & $(6)$ & $(7)$ & $(8)$ \\
& $\begin{array}{c}\Delta \text { Total } \\
\text { public } \\
\text { education } \\
\text { spending }\end{array}$ & $\begin{array}{c}\Delta \text { Public } \\
\text { tertiary } \\
\text { education } \\
\text { spending }\end{array}$ & $\begin{array}{c}\Delta \text { Total } \\
\text { public } \\
\text { education } \\
\text { spending }\end{array}$ & $\begin{array}{c}\Delta \text { Public } \\
\text { tertiary } \\
\text { education } \\
\text { spending }\end{array}$ \\
Variable & -0.0180 & 0.00249 & -0.0166 & 0.00290 \\
Female labor force & $(0.0188)$ & $(0.0118)$ & $(0.0168)$ & $(0.0113)$ \\
$\quad$ particip. rate $(\Delta)$ & 0.0712 & 0.00432 & 0.0832 & 0.00211 \\
Succession (dummy) & $(0.0613)$ & $(0.0253)$ & $(0.0666)$ & $(0.0263)$ \\
& $1.83 e-05$ & $4.24 \mathrm{e}-05$ & $6.41 \mathrm{e}-05$ & $5.78 \mathrm{e}-05$ \\
Cabinet duration & & & & \\
$\quad$ (days) & $(7.25 \mathrm{e}-05)$ & $(4.04 \mathrm{e}-05)$ & $(7.31 \mathrm{e}-05)$ & $(4.67 \mathrm{e}-05)$ \\
Constant & 0.152 & -0.165 & -0.0807 & -0.276 \\
& $(0.568)$ & $(0.401)$ & $(0.450)$ & $(0.399)$ \\
\hline Observations & 74 & 74 & 74 & 74 \\
Countries & 21 & 21 & 21 & 21 \\
R-squared & 0.626 & 0.241 & 0.627 & 0.269 \\
Wald Test & $403.8^{* * *}$ & 12.42 & $580.3^{* * *}$ & $24.93^{* *}$ \\
\hline
\end{tabular}

Notes: Standard errors in parentheses. Significance levels: ${ }^{* *} p<0.01 ;{ }^{* *} p<0.05$ $* \mathrm{p}<0.1$.

\section{Results: direct vs indirect measures of party positions}

To investigate whether a direct measure of party preferences alters the results, we exchange the cabinet seat-shares of social democrats by our manifesto-based measure. We might expect that parties that place more emphasis on education in their manifestos increase spending more than parties with lower emphasis. Empirically, however, the variable has no substantial effect either (Table 2, models 7 and 8 ). Additionally, we include the party family seat-shares and the manifesto item simultaneously (following Ansell [2010]), as well as an interaction between the two to investigate whether social democrats, who strongly emphasize education, act differently. Again, however, we do not find any confirming results.

The only robust effect over all models is that education spending grows when total government spending increases. This seems plausible, but also rather trivial. The other control variables have no significant effects, with the exception of trade openness, which has a small positive effect on total public education spending. While several authors found a relationship between globalization and education (e.g., Ansell 2008, 2010; Boix 1998; Busemeyer 2009), the effect is not sufficiently robust across model specifications to interpret it substantially. We also tested Boix's (1998) and Busemeyer's (2009) argument that social democrats in open economies increase education spending 'to cushion the impact of economic internationalization for their core electoral constituencies' 
(Busemeyer 2009: 119). However, the interaction between the cabinet share of social democrats and trade openness is not a significant predictor of tertiary spending in our government-term models. Moreover, trade openness is only significant in some random-effects models and not in fixed-effects estimations the effect might be driven by the Scandinavian countries, which are historically open economies and also characterized by large education budgets.

In sum, our claim that the literature's use of annual observations leads to incorrect estimations receives strong support. When using government terms as the unit of analysis, we do not find any evidence that the partisan composition of government had any significant effect on (total or sectoral) public education spending during the period from 1995 to 2010; that is, we neither find that social democrats spend more on education than other party families, nor that parties that place more emphasis on education spend more. ${ }^{11}$

\section{SO PARTIES NEVER MATTERED?}

While some readers might infer that parties do not matter for education spending, we abstain from doing so for several reasons, the major one being that for reasons of data availability we had to focus on the post-1995 period. This is problematic because scholars in a parallel literature - in fact unconnected to the expenditure-focused studies - argued from a historical institutionalist perspective that countries' education systems have been shaped a long time ago, mainly in the immediate post-war years (Busemeyer 2014; Garritzmann 2014; Iversen and Stephens 2008; Thelen 2004). These studies demonstrated in historical comparative case studies that governments during the immediate post-war decades designed the skill formation regimes according to their ideological beliefs and constituencies' interests.

In Scandinavia, for example, large left-wing majorities backed by powerful unions established comprehensive schooling, expanded access to higher education massively and increased public expenditure considerably already during the 1950s to the 1970s (Busemeyer 2014; Garritzmann 2014; Iversen and Stephens 2008). In continental Europe, at the same time, education systems were shaped by 'cross-class coalitions' between Christian democrats, business associations, and unions, leading to strong vocational education and lower public education spending, particularly for higher education (Busemeyer 2014; Thelen 2004). In liberal welfare states the politico-economic actors from the 1950 s to 1970 s widened access to education as in Scandinavia, but shifted the financial burden to private households (Busemeyer 2014; Iversen and Stephens 2008), particularly in higher education (Garritzmann 2014). In Japan and other Asian and Latin American countries, finally, the ruling conservative parties strictly limited access to and public spending on higher education and 'outsourced' enrolment expansion into the private, tuition-dependent sector (Garritzmann 2014). In sum, these studies showed that today's education systems can largely be explained by the government composition during the two or three immediate post-war decades. 
Moreover, these historical institutionalist studies argued that decisions made in this formative phase generated path dependencies, reinforced by 'positive feedback effects' on the mass-public level (Pierson 1993, 2000), which set incentives for political parties to follow along the existing paths and have made radical policy change electorally costly for parties (Busemeyer et al. 2011; Garritzmann 2015). For example, in countries with considerable tuition fees, it becomes increasingly difficult for governments to switch back to a publicly funded system, because former students do not want to 'pay twice', first for their own and then for others' education (Garritzmann 2014, 2015). Therefore, education spending becomes increasingly 'locked in' and rather immune to (radical) change over time. ${ }^{12}$

Following these studies, we could expect to find strong partisan effects during the formative years of the education systems, but as the systems might become increasingly locked-in over time, the room to manoeuvre for parties could close and radical policy changes could become increasingly unlikely. As our findings (that parties don't matter anymore) fit very well to these historical institutionalist arguments, we emphasize that our results should not be interpreted as evidence that parties have never mattered. We simply show that when estimating effects more accurately, we do not find evidence for effects during the most recent phase. In Online Appendix C, we offer additional empirical material for these claims, revealing a strong relationship between today's expenditure and the composition of government in the immediate post-war decades.

\section{CONCLUSION}

Education systems and policies have recently received considerable attention in political science (Busemeyer and Trampusch 2011; Gift and Wibbels 2014; Iversen and Stephens 2008; Jakobi et al. 2010). At the core of this research are studies probing whether and how governing parties have shaped skill formation regimes. Most of these studies focus on spending as an easily comparable policy output and regress public education expenditure on cabinet seat-share weighted party-family dummies in time-series cross-section (TSCS) regressions using 'country-years' as the unit of analysis.

We challenged this widely accepted procedure on theoretical, methodological and empirical grounds. Theoretically, we incorporated arguments from recent historical institutionalist analyses (Busemeyer 2014; Garritzmann 2014, 2015; Iversen and Stephens 2008; Thelen 2004), demonstrating that parties did exercise influence on education systems during the immediate post-war decades, but that their leeway in redesigning the systems has constantly decreased over time. Accordingly, in contrast to the existing quantitative literature, we argued that it is not likely to find effects of the partisan composition of government on public education spending for the period of data availability (1995-2010).

Second, we challenged the literature from a methodological perspective, questioning the common wisdom that TSCS regressions on annual basis are the 
'gold standard' of macro-level political economy analyses. We showed that using country-years artificially inflates the number of cases when one is interested in effects of governments, because governments usually do not change annually. As common approaches therefore try to explain variance with non-variance, the existing studies' results are likely to be biased. We proposed using government terms as the unit of analysis instead and controlled for government duration. This approach has beneficial side-effects, as problems arising from complex time structures are challenging in country-year approaches, but are alleviated in the government-term approach. Consequently, we appeal to scholars interested in partisan effects on policy outputs to think about whether a standard 'country-year' TSCS regression is appropriate.

Third, we challenged the common procedure to use left-right or party-family dummies as proxies for party positions, as these might lead to incorrect estimates of parties' impact on spending. This is so because left-right and party-family approaches have to assume that parties within party families hold identical positions and that parties of different families hold distinct positions. Yet, these assumptions often do not hold empirically. Instead, we proposed using direct measures of parties' preferences.

Empirically, we tested whether the partisan composition of government affects total and/or sectoral public education spending, comparing results from country-year to government-term analyses. While we do find effects when using the country-year approach, these effects vanish in a governmentterm design. Here, we find that governments did not have any significant impact on public spending education between 1995 and 2010. This finding holds irrespective of operationalizations and model specifications. Thus, we question the literature's common finding that parties still matter.

Future studies could analyse how party competition influences spending. Jensen (2010), for example, demonstrated that right-wing parties in countries with predominant left-wing parties spend more than right-wing parties elsewhere (and even more than left-wing parties). One could take these findings as a starting point and investigate influences of party competition on (education) spending.

Methodologically, subsequent studies could go further along the lines suggested in this article and try to estimate parties' impact on (education) spending more accurately. One could pick up the criticism that the decision-making authority over education policy lies in some countries on a subnational level. Moreover, we could use different direct operationalizations of party preferences to improve the results further. This article also underlined the need for data covering longer time periods, as comparative data on the sectoral level are available only since the mid-1990s. Finally, one could transfer our theoretical and methodological claims to other policy fields where they should equally hold.

Biographical notes: Julian L. Garritzmann is postdoctoral researcher at the University of Konstanz. Kilian Seng is Head of the Method Center at the Zeppelin University Friedrichshafen. 
Addresses for correspondence: Julian L. Garritzmann, Postdoctoral Researcher, Department of Politics and Public Administration, University of Konstanz, Fach D 79, 78457 Konstanz, Germany. email: julian.Garritzmann@uni-konstanz.de / Kilian Seng, Head of the Method Center, Zeppelin University Friedrichshafen, 88045 Friedrichshafen. email: kilian.seng@zu.de

\section{ACKNOWLEDGMENTS}

We are grateful for valuable comments from Aurélien Abrassart, Michael Becher, Christian Breunig, Marius Busemeyer, Erik Neimanns, Susanne Münn, Carina Schmitt, Janis Vossiek, and from two anonymous reviewers, as well as from JEPP's editors. Lina Seitzl and Tobias Tober provided valuable research assistance. Leonce Röth generously provided data on parties' government participation. Julian Garritzmann's research was supported by the German Research Foundation's Emmy-Noether-Program (grant number BU-1852/4-1) and by the Graduate School of Decision Sciences, University of Konstanz.

\section{SUPPLEMENTAL DATA AND RESEARCH MATERIALS}

Supplemental data for this article can be accessed on the Taylor \& Francis website, http://dx.doi.org/10.1080/13501763.2015.1048703.

\section{NOTES}

1 For analyses of private education spending, see Busemeyer (2014) and Garritzmann (2014).

2 Recent contributions showed that Christian democrats were equally important for the development of welfare states (e.g., Huber et al. 1993).

3 This category excludes technical training, which is coded under 'per411', the only issue that has a related topic (Volkens et al. 2011). Somewhat in contrast to its theor etical background in salience theory, the CMP also includes some positional, i.e., two sided items. This is also the case for education: 'Education limitation' (per507) is defined as 'per506' in the negative. 'Per507' is, however, one of the items with the fewest mentions (Busemeyer et al. 2013) and does not work as a sat isfactory measure of issue salience.

4 We additionally split the sample in unitary and federal states, which leaves the results unaltered for unitary states, while the sample of federal states becomes too small for analysis, given the number of covariates.

5 Australia, Austria, Belgium, Canada, Denmark, Finland, France, Germany, Greece, Ireland, Italy, Japan, Netherlands, New Zealand, Norway, Portugal, Spain, Sweden, Switzerland, United Kingdom, United States.

6 As is customary, we divide spending by GDP for reasons of comparability.

7 However, this neglects the sequence of government terms.

8 We do not consider governments that have been in office less than one year, as they might not even be able to run through the legislative household procedure. In some cases, if the previous government(s) governed less than one year, governments do not follow each other directly. We control for this with a dummy ('succession'), but there is no systematic effect. (Because of missing observations and the fact 
that we lose 21 observations when building first differences, we end up with 74 observations in the models presented below.)

9 For reasons of space availability we are not able to present all results, but offer them on request.

10 The Wald test in model 6 does not even allow rejecting the null hypothesis.

11 Besides spending, we also used tertiary enrollment levels as an alternative dependent variable, following Busemeyer (2009). Yet, there is no robust effect either.

12 The finding of path dependencies is partly also in line with other interpretations, such as Jensen's (2011) argument that spending is unaffected by parties, claiming that the main driver of expenditure is deindustrialization, which increases (high skilled) workers' demand for education, at least in CMEs. But as we do not find direct empirical evidence for Jensen's deindustrialization argument and as our finding holds for both CMEs and liberal market economies (LMEs), our findings seem better explained by the historical institutionalist perspective. Unfortunately, space availability restricts discussion of these interpretations in due length.

\section{REFERENCES}

Ansell, B.W. (2008) 'University challenges: explaining institutional change in higher education', World Politics 60(2): 189230.

Ansell, B.W. (2010) From the Ballot to the Blackboard - the Redistributive Political Economy of Education, Cambridge: Cambridge University Press.

Boix, C. (1998) Political Parties, Growth and Equality - Conservative and Social Democratic Economic Strategies in the World Economy, Cambridge: Cambridge University Press.

Bonoli, G. (2007) 'Time matters: postindustrialization, new social risks, and welfare state adaptation in advanced industrial democracies', Comparative Political Studies 40(5): 495520.

Bräuninger, T. and Debus, M. (2008) 'Der Einfluss von Koalitionsaussagen, program matischen Standpunkten und der Bundespolitik auf die Regierungsbildung in den deutschen Ländern', Politische Vierteljahresschrift 49(2): 30938.

Busemeyer, M.R. (2006) 'Der Kampf um knappe Mittel: Die Bestimmungsfaktoren der öffentlichen, privaten und sektoralen Bildungsausgaben im OECD Länder Vergle ich', Politische Vierteljahresschrift 47(3): 393418.

Busemeyer, M.R. (2007) 'Determinants of public education spending in 21 OECD democracies, 1980 2001', Journal of European Public Policy 14(4): 582610.

Busemeyer, M.R. (2009) 'Social democrats and the new partisan politics of public investment in education', Journal of European Public Policy 16(1): 10726.

Busemeyer, M.R. (2014) Skills and Inequality: Partisan Politics and the Political Economy of Education Reform in Western Welfare States, Cambridge: Cambridge University Press.

Busemeyer, M.R., Cattaneo, M.A. and Wolter, S.C. (2011) 'Individual policy prefer ences for vocational versus academic education: microlevel evidence from the case of Switzerland', Journal of European Social Policy 21(3): 25373.

Busemeyer, M.R., Franzmann, S.T. and Garritzmann, J.L. (2013) 'Who owns edu cation? Cleavage structures in the partisan competition over educational expansion', West European Politics 36(3): 52146.

Busemeyer, M.R. and Trampusch, C. (2011) 'Review article: comparative political science and the study of education', British Journal of Political Science 41: 41343.

Castles, F.G. (1982) 'The impact of parties on public expenditure', in F.G. Castles (ed.), The Impact of Parties: Politics and Policies in Democratic Capitalist States, London: Sage, pp. 2196. 
Castles, F.G. (1989) 'Explaining public education expenditure in OECD nations', European Journal of Political Research 17(4): 43148.

Castles, F.G. (1998) Comparative Public Policy: Patterns of Postwar Transformation, Cheltenham: Edward Elgar.

Cusack, T.R. and Engelhardt, L. (2002) 'The PGL file collection: file structures and procedures', Wissenschaftszentrum Berlin für Sozialforschung, available at http:// www.wzb.eu/sites/default/files/+wzb/bal/usi/pgl structures and procederes ce.pdf (accessed 15 March 2014).

Esping Andersen, G. (1990) The Three Worlds of Welfare Capitalism, Cambridge: Polity Press.

Esping Andersen, G. 2002. Why we Need a New Welfare State, Oxford: Oxford Univer sity Press.

Garritzmann, J.L. (2014) 'The political economy of higher education finance. a com parative analysis of the politics of tuition fees and subsidies', dissertation, University of Konstanz.

Garritzmann, J.L. (2015) 'Attitudes towards student support. How positive feedback effects prevent change in the Four Worlds of Student Finance', Journal of European Social Policy 25(2): 3958.

Gift, T. and Wibbels, E. (2014) 'Reading, writing, and the regrettable status of educa tion research in comparative politics', Annual Review of Political Science 17: 291312.

Hall, P.A. and Soskice, D. (2001) Varieties of Capitalism: The Institutional Foundations of Comparative Advantage, Oxford: Oxford University Press.

Hega, G.M. and Hokenmaier, K.G. (2002) 'The welfare state and education: a com parison of social and educational policy in advanced industrial societies', Politikfeldanalyse/German Policy Studies 2(1): 129.

Heidenheimer, A.J. (1996) 'Throwing money and heaving bodies: Heuristica callisthe nics for comparative policy buffs'. in L.M. Imbeau and R.D. McKinlay (eds), Comparing Government Activity, Basingstoke: Macmillan, pp. 1325.

Hibbs, D.A. (1977) 'Political parties and macroeconomic policy', American Political Science Review 71: 146787.

Huber, E., Ragin, C. and Stephens, J.D. (1993) 'Social democracy, Christian democ racy, constitutional structure, and the welfare state', American Journal of Sociology 99(3): 71149

Iversen, T. (2005) Capitalism, Democracy, and Welfare, Cambridge: Cambridge University Press.

Iversen, T. and Cusack, T.R. (2000) 'The causes of welfare state expansion deindus trialization or globalization?', World Politics, 52(3): 31349.

Iversen, T., and Stephens, J.D. (2008) 'Partisan politics, the welfare state, and three worlds of human capital formation', Comparative Political Studies 41(4 5): 60037.

Jakobi, A.P., Martens, K. and Wolf, K.D. (eds) (2010) Education in Political Science: Discovering a Neglected Field, Abingdon: Routledge.

Jensen, C. (2010) 'Issue compensation and right wing government social spending', European Journal of Political Research 49(2): 28299.

Jensen, C. (2011) 'Capitalist systems, deindustrialization, and the politics of public edu cation', Comparative Political Studies 44(4): 41235.

Jungblut, J. (2014) 'Bringing political parties into the picture: a two dimensional analytical framework for higher education policy', Higher Education 69(5): 86782.

Mair, P. (2001) 'Searching for the position of political actors: a review of approaches and a critical evaluation of expert surveys', in M. Laver (ed.), Estimating the Policy Positions of Political Actors, London: Routledge, pp. 1030.

Persson, T., Roland, G. and Tabellini, G. (2007) 'Electoral rules and government spending in parliamentary democracies', Quarterly Journal of Political Science 2(2): 15588. 
Pierson, P. (1993) 'When effect becomes cause: policy feedback and political change', World Politics 45: 595628.

Pierson, P. (2000) 'Increasing returns, path dependence, and the study of politics', American Political Science Review 94(2): 25167.

Plümper, T., Troeger, V. and Manow, P. (2005) 'Panel data analysis in comparative politics: linking method to theory', European Journal of Political Research 44: 32754

Potrafke, N. (2011a) 'Does government ideology influence budget composition? Empirical evidence from OECD countries', Economics of Governance 12(2): 10134.

Potrafke, N. (2011b) 'Public expenditures on education and cultural affairs in the West German states: does government ideology influence the budget composition?', German Economic Review 12(1): 12445.

Rauh, C., Kirchner, A. and Kappe, R. (2011) 'Political parties and higher education spending: who favours redistribution?', West European Politics 34(6): 1185206.

Schmidt, M.G. (1996) 'When parties matter: a review of the possibilities and limits of partisan influence on public policy', European Journal of Political Research 30(2): 15583.

Schmidt, M.G. (2002) 'Warum Mittelmaß? Deutschlands Bildungsausgaben im inter nationalen Vergleich', Politische Vierteljahresschrift 43(1): 319.

Schmidt, M.G. (2007) 'Testing the retrenchment hypothesis: education spending, 1960 2002', in F.G. Castles (ed.), The Disappearing State? Cheltenham: Edward Elgar, pp. 15983.

Schmitt, C. (2013) 'Panal data analysis and public spending', Paper presented at the Workshop on Parties, Welfare, and Education, Harvard University, 9 December.

Thelen, K. (2004) How Institutions Evolve: The Political Economy of Skills in Germany, Britain, the United States and Japan, Cambridge: Cambridge University Press.

Verner, J.G. (1979) 'Socioeconomic environment, political system, and educational policy outcomes: a comparative analysis of 102 countries', Comparative Politics 11(2): 16587

Vis, B. (2011) 'Under which conditions does spending on active labor market policies increase? An fsQCA analysis of 53 governments between 1985 and 2003', European Political Science Review 3(2): 22952.

Vis, B. (2012) 'The comparative advantages of fsQCA and regression analysis for mod erately large N analyses', Sociological Methods \& Research 41(1): 16898.

Volkens, A., Lacewell, O., Regel, S., Schultze, H. and Werner, A. (2011) The Manifesto Data Collection: Manifesto Project (MRG/CMP/MARPOR), available at https://mani festo project.wzb.eu/\# (accessed March 2014).

Wolf, F. and Zohlnhöfer, R. (2009) 'Investing in human capital? The determinants of private education expenditure in 26 OECD countries', Journal of European Social Policy 19: 23044. 